\title{
The Effect of the Characteristics of Audit Committees on Internal Control: An Empirical Study of the French Context
}

\author{
Abdelhakim Ben Ali ${ }^{1 *}$ and Amine Bakkeri ${ }^{2}$ \\ ${ }^{1}$ Faculty of Law, Economics and Management of Jendouba, \\ University of Jendouba, Tunisia. \\ ${ }^{2}$ Faculty of Economics and Management of Sfax, University of Sfax, Tunisia.
}

\begin{abstract}
This article reports on an empirical study of Société des Bourses Françaises (SBF)'s 250 French companies on the list of the Paris Stock Exchange over the period 2012-2018. It focussed on the characteristics of audit committees, examined the interaction between audit committees and the internal quality control system. Panel data was the framework used for this research. Data was collected manually from annual reports and reference documents. After a selection procedure we obtained a sample of 162 French companies and a total of 1134 observations of company years. Data analysis indicated that financial expertise, independence, frequency of meetings, and size of the audit committees positively and significantly impacted internal control weaknesses. Likewise, women's participation in audit committees was significantly correlated with the mitigation of internal control problems. This research enriches the current debate on the effectiveness of internal control bodies within companies and demonstrates ways to enhance audit committees implement quality control. Unavailability of data, the size, and the choice of companies selected for this sample constitute the shortcomings in this research. While these limitations can reduce the explanatory power of the model presented, they can serve as a basis for future research.
\end{abstract}

Keywords: Audit Committee, Financial Expertise, Audit Committee Independence, Internal Control, France.

\section{$\underline{\text { ARTICLE INFO }}$}

\section{Article History:}

Received: 23 May 2021

Accepted: 13 October 2021

Available online: 01 December 2021

\footnotetext{
* Corresponding Author: Abdelhakim Ben Ali, Faculty of Law, Economics and Management of Jendouba, University of Jendouba, Avenue of U.M.A, 8189 Jendouba, Tunisia; Email: benali.abdelhakim@gmail. com; Tel: (+216) 20670609
} 


\section{INTRODUCTION}

The financial crises that have recently rocked the business community have brought the integrity of governance practices back onto the agenda. For example, the financial security law of August 1, 2003, intended to restore investor confidence in the transparency of financial information. This law, which comes on the heels of the American Sarbanes-Oxley law of July 30, 2002, stipulates that shareholder and the market be notified of the internal control procedures put in place in public limited companies (Cappelletti, 2006). In a context where users suspect the reporting financier and lose confidence in published financial statements, much effort now tends to focus on redefining a firm's internal governance bodies, including establishing audit committees operating under the aegis of the boards of directors (Ghafran and Yasmin, 2018). According to Bédard et al., (2004) audit committees are responsible for the reliability of the financial statements and the information they contain. Several previous studies have found that when audit committees sit on the board of directors' meetings, their presence improves the reliability of the financial information that companies issue (Pucheta-Martínez et al., 2016).

The audit committee is a legal requirement in some countries like the United States and Canada. It is an index of good governance in other countries like Great Britain where its formation is optional. Several investors believe that this modern governance and control mechanism guarantees their interests as they often deem annual reports to be inadequate (Ghafran and O'Sullivan, 2013). As such, audit committees should be part of the supervisory mechanism. They constitute an original privileged mechanism for improving corporate governance (Gurusamy, 2017).

Further, the growing complexity of companies means that the financial audit function should no longer be part of an independent operation to be conducted by an external body. Instead, financial auditing is viewed as a complex process integrating the work carried out by internal control services. In this systemic vision, audit committees are tasked with coordinating the due diligence of internal and external auditors. They allay the concern of mobilizing the means deemed necessary for the integrity of the audit process and optimize its use (Bimo et al., 2019). To this effect, Versehoor (1993) and Blue Ribbon Committee (1999) identified audit committees' responsibilities 
as inclusive of the internal control system, annual reports, and external audit. Ignored at first, audit committees have gradually become a common practice among large companies (Collier and Gregory, 1999). Today, they constitute an essential monitoring mechanism and a critical tool for administrators to better discharge their responsibilities in matters of governance.

To tackle this research question, this paper will be structured as follows. The first section reviews the literature on audit committees and the hypotheses often associated with such committees. The next section is dedicated to the development of the hypotheses for this study. In the third section, we describe the sample, the research model selected for this study, and the results of our econometric analysis. The last section provides a summary of our findings and their implications, identifies the limits of the study, and suggests future research avenues.

\section{BACKGROUND AND HYPOTHESES}

The central objective of audit committees is to review the process of preparing financial information in accordance with the rule of law and the preservation of the public interest. The second objective is to put in place continuous monitoring systems of internal control. Our review of the literature begins by recalling the relationship between audit committees and internal control. We then explore the characteristics of the audit committee, with a focus on its members' expertise, its independence, the number of meetings it holds, its size and gender diversity. There appears to be no universally accepted definition of audit committees in regulations, reports, surveys, and research studies (Klein, 2002; Miglani, and Ahmed, 2019; Agyei-Mensah, 2019). According to Zhang et al., (2007), the audit committee represents one of the mechanisms of corporate governance through which shareholders hope to restrain the directors' behaviors. In this sense, audit committees are fundamental for internal control. The board of directors' mandated responsibility is that the directors supervise the entire control process. Subsequently, continuous monitoring of control is delegated to some of the directors, who will be the "eyes" of the board and will sit on the audit committee. 
Several authors point out that detecting weaknesses in the internal control system and examining the accounts before their submission to the board rest on the experience of the audit committee members to make decisions relating to the evaluation of the internal control system (DeZoort, 1998 ; Agyei-Mensah et al., 2020). This is because members not experienced in audit or internal control are likely to make judgments that are not optimal because they do not have the technical knowledge in accounting and auditing necessary for their duty of diligence. Likewise, Oussii and Boulila Taktak (2018) suggest various characteristics audit committees should have so that they are effective and can make the necessary recommendations.

\section{Expertise of Audit Committee Members}

To fulfil their responsibilities for overseeing internal control and disclosing financial information, members of the audit committee must have the necessary expertise (Lisic et al., 2019). Several studies indicate that audit committee members will be more efficient in their work if its members have expertise in the fields of accounting, auditing, internal control, and financial reporting (Chen \& Komal, 2018; Rohana et al., 2014). Other studies indicate a significant relationship between audit committees' financial expertise and how the results are managed (Inaam and Khamoussi, 2016; Khemakhem and Fontaine, 2019). Based on these studies, we suggest that companies with expert members in accounting and finance on its audit committee benefit from a higher level of internal control quality. So, we state the following hypothesis:

H1: Expertise possessed by audit committee members has a positive and significant effect on detecting internal control weaknesses.

\section{Independence of the Audit Committee}

In addition to financial expertise, audit committees should acquire other characteristics necessary for effective oversight (Krishnan, 2005). Audit committees must be independent of a firm's management to discharge their oversight duty better and protect shareholders' interests. Thus, the independence of audit committees is an essential quality for them to fulfil their oversight role (Choi et al., 2004). Bouaine and Hrichi (2019) identified the independence of audit committee members as one of the most important characteristics required to guarantee a good quality financial information. 
According to Zhang et al., (2007), there is a positive relationship between the independence of the audit committee and the quality of internal control. The independence of directors will allow members of the audit committee to exercise their oversight role properly. Likewise, the presence of external directors on audit committees can reduce managers' opportunistic behavior and minimize the likelihood of receiving reports which do not say everything about the sustainability of the business. Firms with independent audit committees have been less sanctioned by the Securities and Exchange Commission (SEC) because of fraudulent financial statements (Abbott et al., 2000; Vlaminck and Sarens, 2015; Porettia et al., 2018). Considering these mixed empirical findings, we measured the independence of the audit committee by the percentage of external directors. Based on above analysis, we submit the following hypothesis:

H2: The independence of the audit committee has a positive and significant effect on the detection of weaknesses in internal control.

\section{Frequent Meetings of the Audit Committee}

Situated between internal audit and external audit, the audit committee plays a vital role in company performance. According to Retnoningrum et al., (2018), one performance measure for audit committees is how frequently they meet; the audit committee's number of meetings reflects their oversight effectiveness (Bédard and Gendron, 2010; Alkilani et al., 2019). Besides, the number of meetings conducted by audit committees correlates with the improved quality of financial reports. Indeed, more audit committee meetings can increase their efficiency and ensure more effective supervision of the company's financial statements (Vlaminck and Sarens, 2015; Sultana, 2015). According to Al-Baidhani (2016), audit committee meetings significantly impact the evaluation of its overall performance and internal control functions.

Alzeban and Sawan (2015) and Naiker and Sharma (2009) showed that the higher the frequency of audit committee meetings, the lower the weaknesses in internal control. Likewise, much research dwells on the value accorded to how frequently audit committees meet. Furthermore, Al-Najjar (2011) has shown that companies with larger audit committees and larger boards with more frequent meetings are active and require more audit 
committee meetings. Various studies have also indicated that the frequency of audit committee meetings significantly correlates with a reduction in the risks of internal control. (Krishnan, 2005; Sarens et al., 2009; Lisic et al., 2016). Referring to the findings of these studies, we formulated the following hypothesis:

H3: There is a positive relationship between the frequency of meetings of the audit committee and the perception of internal control weaknesses.

\section{Size of the Audit Committee}

Several studies have shown that larger audit committees are more efficient when comprising members with different knowledge and expertise who function more reliably in overseeing financial processes. Besides, if the audit committee is composed of a large number of members, it can help to uncover and resolve the questions and problems raised throughout the internal control process (Alzoubi, 2019). García et al., (2012) have also found that audit committees with more members can better monitor the quality of financial information and internal control.

For Oussii and Boulila Taktak (2018), audit committee effectiveness is contingent upon a sufficient number of committee members who will perform its work. Moreover, various empirical studies have shown that audit committee size significantly affects risk management, financial disclosure, and the internal control monitoring process. (Sultana et al., 2015; Asiriuwa et al., 2018). The following hypothesis was formulated:

H4: The relationship is positive between the size of audit committees and the perception that internal audit recommendations are implemented.

\section{Gender Diversity}

To safeguard and protect shareholders' interests, the main mechanisms that play an important supervisory role on behalf of shareholders are the board of directors and the audit committee (Aldamen et al., 2019; Darmayanti and Md Kassim, 2019). According to Adams and Ferreira (2009), the inclusion of women on the board of directors in the audit committee adds diversity and strengthens internal control oversight efforts. 
Nekhili et al., (2020) suggested that gender diversity responds to companies' desire to improve the quality of the cognitive process. As a result, women's membership in audit committees allows the emergence of new ideas and opens interesting perspectives (Francoeur et al., 2008; Beasley et al., 2009). Several studies have hypothesized that women's presence on audit committees is likely to reduce the possibility that the results are manipulated (Sun et al., 2011). Women's presence is also shown to improve the internal control system (Ittonen et al., 2010). Sun et al., (2011) submitted that women can detect risks and exhibit more ethical behavior. As a result, having women on committees would provide more effective oversight:

H5: Women's presence in audit committees has a positive and significant effect on detecting weaknesses in internal control.

\section{RESEARCH DESIGN AND METHODOLOGY}

\section{Sample and Data}

This empirical study relates to the companies of the Société des Bourses Françaises (SBF)'s 250 index comprising the 250 largest French companies that were on the list of the Paris Stock Exchange over the period 2012-2018. Data was collected manually from annual reports and reference documents. We excluded banks, insurance companies, and real estate companies because of their specific accounting presentation and their regulations in the field of auditing. We also discarded companies for which specific data were missing. This selection procedure allowed us to maintain a sample of 162 French companies, yielding 1134 observations of company years in total.

\section{Research Model and Variables Measurement}

$$
\begin{aligned}
& \mathrm{ICW}_{\text {it }}=\alpha_{0}+\alpha_{1} \mathrm{ACFE}_{\mathrm{it}}+\alpha_{2} \mathrm{ACIND}_{\text {it }}+\alpha_{3} \mathrm{ACMEET}_{\text {it }}+\alpha_{4} \mathrm{ACSZ}_{\text {it }}+ \\
& \alpha_{5} \text { FEMAC }_{\text {it }}+\alpha_{6} \text { SIZE }_{\text {it }}+\alpha_{7} \text { ACQUIS }_{\text {it }}+\alpha_{8} \text { REST }_{\text {it }}+\alpha_{9} \text { FOREIGN }_{\text {it }} \\
& +\varepsilon_{\text {it }}
\end{aligned}
$$

\section{Dependent variable}

ICWit: Weaknesses in internal control. These weaknesses may result from the absence of competent staff with adequate qualifications, 
poor income accounting, poor documentation, and outdated information technology systems. It takes the value 1 if company $i$ at moment $t$ has internal control weaknesses. Otherwise, it takes the value 0 .

\section{Independent variables}

ACFEit : The financial expertise of the audit committee. This is the percentage of the audit committee members of company $i$ at moment $t$ who are experts in accounting, finance, or management.

ACINDit : The independence of the audit committee. This is the percentage of external directors on the audit committee of enterprise $i$ at time t. A director is independent if he/she has no relationship with the company, which may interfere with the exercise of their functions.

ACMEETit : Audit committee meetings. It is the number of meetings convened by company $i$ at time $t$. This variable was measured by the natural logarithm of the number of meetings.

ACSZit : The size of the audit committee. It is the number of members on the audit committee of companies $i$ at time $t$.

FEMACit : This is the number of women members present on the audit committee of companies $i$ at time $t$.

\section{Control variables}

SIZEit: The size of the business. This variable was measured by the natural logarithm of the total assets of enterprise $i$ at time $t$.

ACQUISit : The acquisitions carried out by the company. A company that has recently engaged in mergers or acquisitions may need an adjustment period to integrate the various internal control systems, which makes weakness more likely. It takes the value 1 if acquisitions or mergers are carried out by company $i$ during year $t$ and takes the value 0 if no acquisitions were undertaken.

RESTit : The restructuring carried out by the company. An organization that has recently engaged in restructuring may experience internal control weaknesses due to losing some experienced employees. It takes the value 
1 if there are restructurings carried out by company $i$ at the time $t$ and 0 if no restructurings were carried out.

FOREIGNit : Foreign currency transactions. These transactions constitute a dummy variable that takes the value 1 if the entity i carries out operations in foreign currency during the year $t$ and 0 if no such transactions are carried out.

\section{REGRESSION RESULTS AND INTERPRETATIONS}

\section{Hausman Specification Test}

Table 1: Hausman Specification Test

\begin{tabular}{lcccc}
\hline \multicolumn{4}{c}{ Coefficients } & \multicolumn{2}{c}{ sqrt(diag(V_b-V_B)) } \\
\hline & $\mathbf{( b )}$ & $\mathbf{( B )}$ & $\mathbf{( b - B )}$ & S.E. \\
\hline FCFE & 2.3764 & 2.6372 & 0.2061 & 2.3665 \\
ACIND & 3.0526 & 2.1799 & 0.8727 & 4.581 \\
ACMEET & 1.3801 & 5.8162 & 0.5264 & 0.8896 \\
ACSZ & -0.5925 & 1.0206 & -1.6132 & 2.1068 \\
FEMAC & -0.0132 & -0.0179 & 0.0046 & 0.01626 \\
SIZE & 10.5037 & 3.6022 & 6.9015 & 6.8849 \\
ACQUIS & 12.4476 & 6.6915 & 5.7561 & 9.6360 \\
RESTRUCT & 0.5235 & 0.3970 & 0.1265 & 0.6594 \\
FOREIGN & -1.2180 & -0.2115 & -1.0065 & 0.6690 \\
\hline
\end{tabular}

$\mathrm{b}=$ consistent under $\mathrm{Ho}$ and $\mathrm{Ha}$; obtained from xtlogit

$\mathrm{B}=$ inconsistent under $\mathrm{Ha}$, efficient under $\mathrm{Ho}$; obtained from xtlogit chi2 $(9)=(b-B)^{\prime}\left[\left(V_{-} b-V_{-} B\right)^{\wedge}(-1)\right](b-B)$

$=6.345$

Prob $>$ chi2 $=\mathbf{0 . 0 1 9 4}$

The Hausman Test will suggest that one of the two estimation methods should be considered (estimation methods with random or fixed effects). This test makes it possible to determine if the coefficients of the two estimators are statistically different. The idea is that under the null hypothesis of independence between the errors and the explanatory variables, the two 
estimators are unbiased, so the coefficients should differ little. The result follows a $\chi 2$ law with $\mathrm{k}-1$ degree of freedom. Comparing the tabulated value of $\chi^{2}(\mathrm{k})$ at $95 \%$ with the tabulated value calculated from the Hausman test helped us specify the estimate of the fixed or random effect. Indeed, the probability of this test was less than $10 \%$ (Prob> chi $2=0.0194)$, which implied that the fixed-effects model was more robust than the randomeffects model.

\section{Descriptive Statistics and Pearson Correlations}

Table 2: Descriptive Statistics

\begin{tabular}{lcccccccccc}
\hline & ICW & ACFE & ACIND & ACMEET & ACSZ & FEMAC & SIZE & ACQUIS & REST & FOREIGN \\
\hline Mean & 0.86 & 0.81 & 0.79 & 0.68 & 0.67 & 0.64 & 3.74 & 0.51 & 0.56 & 0.77 \\
Median & 0 & 0.8 & 0.75 & 0.6 & 0.6 & 0.67 & 3.16 & 0.98 & 1 & 1 \\
Maximum & 1 & 1 & 1 & 1.53 & 1.14 & 1 & 6.31 & 1 & 1 & 1 \\
Minimum & 0 & 0.2 & 0 & 0.277 & 0.3 & 0 & 2.96 & 0 & 0 & 0 \\
Std. Dev. & 0.41 & 0.29 & 0.24 & 0.25 & 0.11 & 0.26 & 0.74 & 0.49 & 0.5 & 0.28 \\
\hline
\end{tabular}

For each variable, the number of observations was 1134. Several results are open to discussion. Table 1 gives a synopsis of the descriptive statistics for the different explanatory variables. The results of the descriptive statistics led us to make the following observations. On average, $86 \%$ of audit committees could indeed detect weaknesses in internal control. Close to 81 percent of audit committee members had a professional designation or experience in accounting, finance, or other comparable experience. The percentage of independent members on audit committees was relatively high on average, with a value of $79 \%$.

A tentative conclusion is that French companies tend to include only independent members in their audit committee. The audit committees standing on almost $68 \%$ of the companies in our sample meet at least four times a year, and 67 percent of them contain at least four members. For the FEM_AC variable in our sample, we noted women's presence on committees at the rate of $64 \%$ of the companies. The results are consistent with those of Chen and Komal (2018), Khlif and Samaha (2016), Rich and Zhang (2014), and Krishnan and Visvanathan (2009). 
Table 3: Pearson Correlations

\begin{tabular}{|c|c|c|c|c|c|c|c|c|c|c|}
\hline & ICW & ACFE & ACIND & ACMEET & ACSZ & FEMAC & SIZE & ACQUIS & REST & FOREIGN \\
\hline ICW & 1.000 & & & & & & & & & \\
\hline ACFE & 0.01 & 1.00 & & & & & & & & \\
\hline ACIND & 0.19 & 0.17 & 1.00 & & & & & & & \\
\hline ACMEET & 0.04 & 0.14 & 0.06 & 1.00 & & & & & & \\
\hline ACSZ & 0.14 & 0.31 & -0.18 & 0.22 & 1.00 & & & & & \\
\hline FEMAC & 0.32 & 0.06 & 0.02 & 0.17 & -0.04 & 1.00 & & & & \\
\hline SIZE & -0.01 & -0.10 & -0.04 & -0.32 & -0.16 & 0.03 & 1.00 & & & \\
\hline ACQUIS & -0.01 & -0.07 & 0.14 & 0.04 & -0.08 & 0.10 & -0.10 & 1.000 & & \\
\hline REST & 0.00 & 0.11 & 0.11 & 0.01 & 0.15 & 0.09 & 0.08 & -0.07 & 1.00 & \\
\hline FOREIGN & -0.00 & -0.01 & -0.28 & -0.19 & -0.15 & 0.13 & 0.53 & -0.07 & 0.07 & 1.00 \\
\hline
\end{tabular}

Table 3 presents the correlation coefficients of the variables used in our model. The correlation matrix gives information on the level (high or low) and nature (positive or negative) of the link between the different variables. To bypass the problem of multicollinearity, in other words, to verify the hypothesis of the independence of the explanatory variables, we used the correlation matrix. Before performing the multivariate analysis, it is essential to ensure that too much collinearity between the independent variables will not interfere with the results' interpretation (Asar, 2015). As shown in Table 3, a weak correlation between the different variables constitutes a sufficient condition to reject the existence of a multicollinearity problem. The correlation matrix showed that the explanatory variables were positively correlated with the weakness of internal control. We concluded that the variables (ACFE, ACIND, ACMEET, ACSZ, and FEM_AC) allowed for the detection of internal control weaknesses in the companies under study.

In what follows, we will determine whether the econometric model confirms the validity of these conclusions. 


\section{Econometric Results and Interpretations}

Table 4: Econometric Regression

\begin{tabular}{lcccc}
\hline \multicolumn{1}{c}{ Variables } & Predicted Sign & $\mathbf{z}$ & $\mathbf{P}>|\mathbf{z}|$ & Sig \\
\hline Constante & $+/-$ & 3.7198 & 4.27 & $0.004^{* * *}$ \\
ACFE & + & 2.4737 & 0.492 & $0.007^{* * *}$ \\
ACIND & + & 1.8195 & 0.573 & $0.067^{*}$ \\
ACMEET & + & 0.4131 & 0.252 & $0.042^{* *}$ \\
ACSZ & + & 2.4333 & 1.340 & $0.037^{* *}$ \\
FEMAC & + & 5.6778 & 3.180 & $0.083^{*}$ \\
SIZE & - & -0.3785 & -1.087 & $0.077^{*}$ \\
ACQUIS & - & -0.4131 & -0.067 & $0.328(\mathrm{n} / \mathrm{s})$ \\
RESTRUC & $+/-$ & 0.0309 & 0.085 & $0.297(\mathrm{n} / \mathrm{s})$ \\
FOREIGN & - & -0.5266 & -0.638 & $0.412(\mathrm{n} / \mathrm{s})$ \\
\hline Number of companies & & & 162 & \\
Number of observations & & & 7134 & \\
Wald chi2 & & & 0.0000 & \\
Prob> chi2 & $* * *$ *** : respectively indicate levels of significance at the .10\%, .05\%, and .01\%. \\
\hline
\end{tabular}

In this section, we compare our previously described model to the data panel model. Our goal was to empirically test the impact of the characteristics of the audit committee on the detection of weaknesses in internal control. Multivariate regression analysis indicated that the model selected for our study was statistically significant overall (Wald chi2 (9) $=77.42$; Prob $>$ chi $2=0.0000$ ). In other words, the explanatory variables contributed to the detection of weaknesses in internal control (ICW) at a rate of $77.42 \%$. The results demonstrated that the following variables had a positive and significant effect on the detection of weaknesses in internal control in so far as they relate to audit committees: independence, frequency of meetings, size, and the presence of women. These results are consistent with Klein's (2002) findings on a sample of American companies.

We began our analysis by interpreting the relationship between the expertise of audit committee members and the detection of weaknesses in internal control. Let us recall here that researchers stress the impact of the expertise held by audit committee members in accounting, finance, and management on the detection of weaknesses in internal control (Bédard et 
al., 2004; Lisic et al., 2019). There was a highly significant correlation of $1 \%$ between this variable and the dependent variable (ICW). Therefore, it is urgent to establish audit committees with expert members in accounting, finance, and management to detect weaknesses in internal control. The audit committee's financial expertise is associated with the reliability of internal control, to the extent that financial expertise reduces the probability of disclosing a weakness. Similarly, our results are consistent with Goh (2009) and Zhang et al., (2007). They put forward that the audit committee members' accounting and financial expertise prevents or reduces the probability of internal control weaknesses.

The independence of the audit committee (ACIND) was a positive and significant variable $(0.067)$ around $10 \%(\mathrm{P}>|\mathrm{z}|=0.573)$; independent audit committees accomplish their monitoring mission more effectively, which minimizes weaknesses in internal control (McMullen and Randghum, 1996). This result contrasts with Zhang et al., (2007), who did not find a significant relationship. To explain their result, they refer to the Sarbanes-Oxley law, which required that all audit committee members be independent members.

The relationship between the number of meetings held by the audit committee (ACMEET) and weaknesses in internal control was significant and positive at 5\% (0.042; $\mathrm{P}>|\mathrm{z}|=0.252)$. This finding aligns with Zhang et al., (2007), who considered that the audit committees of companies with weaknesses in their internal control system hold more meetings to remedy these weaknesses. Likewise, we saw a positive and significant effect between the size of audit committees (ACSZ) and their weaknesses. As a result, a large audit committee that is not independent vis-à-vis management or is not active enough cannot effectively perform its tasks. On the other hand, a small committee (with a minimum requirement of three members) can correctly execute its tasks if it is sufficiently active, independent, and endowed with the necessary expertise.

The results showed that the presence of women on audit committees (FEMAC) had a positive and significant impact on the weaknesses of internal control at $10 \%(0.083 ; \mathrm{P}>|\mathrm{z}|=3.180)$; some of the determinants likely to minimize internal control weaknesses are women directors' participation and effective audit committees in the company. These findings showed that women's presence on boards of directors and audit committees improves 
their performance. According to Arun et al., (2015), firms with a higher composition of women and with independent women directors tended to be more conservative in adopting accounting policies. On the other hand, rare studies have examined the level of training and gender of audit committee members. The objective of the internal control bodies, in particular audit committees, minimizes financial, operational risks, and non-conformities. Although equivalent to women's presence on the board of directors, women's presence on audit committees can improve the quality of corporate results (Gull et al., 2017; Lara et al., 2017).

The variable (SIZE) was significant at the $10 \%$ level $(0.077 ; \mathrm{P}>|\mathrm{z}|=$ -1.087) and indicated a negative effect on the weakness of internal control. Thus, the quality of the financial information a company discloses rests on the assumption that its size is a good indicator of its policies' visibility and demonstrates its financial, economic, and competitive performance. However, various studies have predicted that the larger the company, the more operational, organizational, and informational complexity the audit committee finds in carrying out its internal control missions (Bimo et al., 2019).

Our study revealed that the control variables relating to acquisitions (ACQUIS), restructuring (REST), and transactions in foreign currency (FOREIGN) were notably non-determining factors of the dependent variable. However, these variables were negatively associated with the weakness of internal control in the French context.

\section{CONCLUSION}

The purpose of this study was to investigate the impact of the characteristics of audit committees on the weaknesses of internal control. Our research work contributes to the debate on the effectiveness of internal control bodies within companies. Our explanatory model for internal control weaknesses builds upon the characteristics of the audit committee using a sample of 162 French companies.

Several significant results emerge from this exploratory study. Firstly, the results confirmed our hypotheses. Secondly, our analysis indicated five 
essential characteristics: financial expertise, independence, frequency of meetings, size, and women's presence within the audit committee. This research revealed that a higher proportion of members with financial expertise in audit committees is likely to increase the relevance of the results (Qin, 2007) and improve the quality of financial information (Bouaine and Hrichi, 2019) and internal control surveillance (Alzeban and Sawan, 2015).

Another finding is that members' independence is essential for audit committees to operate successfully to guarantee good quality of financial information. Independence allows members to exercise their oversight role properly. Also, audit committees meeting periodically (three to four times a year) are better positioned to detect internal control weaknesses and problems with disclosing financial information (Alkilani et al., 2019). The audit committee size variable had a positive and significant impact on internal control weaknesses. Additionally, the more varied the audit committee's experience, the more they conduct more in-depth monitoring of the internal control system. Such committees can offer strength and a variety of opinions and expertise needed to protect the effective oversight process from internal control. Finally, our results indicated that women's presence in audit committees had a positive and significant impact.

Like any other research work, this study has some limitations. It is conceivable that the unavailability of data, the size, and the choice of companies making up our sample constitute shortcomings for our research work. These limitations can reduce the explanatory power of the model we chose and serve as a basis for future research.

\section{REFERENCES}

Abbott, L.J., Park, Y. and Parker, S. (2000). The effects of audit committee activity and independence on corporate fraud. Managerial Finance, Vol. 26 No. 11, 55-68.

Adams, R. B., and D. Ferreira (2009). Women in the boardroom and their impact on governance and performance. Journal of Financial Economics, 94 (2), 291-309. 
Agyei-Mensah, B. (2019). The effect of audit committee effectiveness and audit quality on corporate voluntary disclosure quality. African Journal of Economic and Management Studies, Vol. 10, No. 1, 17-31.

Agyei-Mensah, B. K., Agyemang, O. S., and Ansong, A. (2020). Audit Committee Effectiveness, Audit Quality, and Internal Control Information Disclosures: An Empirical Study. Corporate Governance Models and Applications in Developing Economies, 1-22.

Al-Baidhani, A. M. (2016). The Role of Audit Committee in Corporate Governance: A Descriptive Study. International Journal of Research \& Methodology in Social Science, Vol. 2, No. 2, 45-57.

Aldamen, H., Duncan, K., Kelly S., McNamara, R. (2019). Corporate governance and family firm performance during the Global Financial Crisis. Accounting \& Finance, Vol. 60, Issue2, 1673-1701.

Alkilani, S. Z., Wan Hussin, W. N., and Basariah S. (2019). The Influence of Audit Committee Characteristics on Modified Audit Opinion in Jordan. Journal of Finance and Accounting, 7, (3): 95-106.

Al-Najjar, B. (2011). The determinants of audit committee independence and activity: evidence from the UK. International Journal of Auditing, Vol. 15, Issue2, 191-203.

Alzeban, A., and Sawan, N. (2015). The impact of audit committee characteristics on the implementation of internal audit recommendations. Journal of International Accounting, Auditing and Taxation, 24, 61-71.

Alzoubi, E. (2019). Audit committee, internal audit function and earnings management: evidence from Jordan. Meditari Accountancy Research, Vol. 27 No. 1, 72-90.

Arun, T. G., Almahrog, Y. E., \& Ali Aribi, Z. (2015). Female directors and earnings management: Evidence from UK companies. International Review of Financial Analysis, 39, 137-146. 
Asar, Y. (2015). Some new methods to solve multicollinearity in logistic regression. Communications in Statistics - Simulation and Computation, 46 (4), 2576-2586.

Asiriuwa O., Aronmwan E., Uwuigbe U., and Uwuigbe O. R. (2018). Audit committee attributes and audit quality: a benchmark analysis. Business: Theory and Practice, 19, 37-48.

Beasley, Mark S., Carcello, Joseph V., Hermanson, Dana R., and Neal, Terry L. (2009). The Audit Committee Oversight Process. Contemporary Accounting Research, 26 (1): 65 - 122.

Bédard, J., \& Gendron, Y. (2010). Strengthening the financial reporting system: Can audit committees deliver?. International journal of auditing, 14 (2), 174-210.

Bédard, J., Chtourou S.M., Courteau, L. (2004). The effect of audit committee expertise, independence, and activity on aggressive earnings management. Auditing: A Journal of Practice \& Theory 23 (2): 13-35.

Bimo, I. D., Siregar, S. V., Hermawan A. A., and Wardhani R. (2019). Internal Control Over Financial Reporting, Organizational Complexity, and Financial Reporting Quality. International Journal of Economics and Management 13 (2), 331-342.

Blue Ribbon Committee (BRC). 1999. Report and Recommendations of the Blue Ribbon Committee on Improving the Effectiveness of Corporate Audit Committees. New York, NY: New York Stock Exchange and National Association of Securities Dealers.

Bouaine, W., and Hrichi, Y. (2019). Impact of Audit Committee Adoption and its Characteristics on Financial Performance: Evidence from 100 French Companies. Accounting and Finance Research, Vol. 8, No.1, 92-102.

Cappelletti, Laurent (2006). Vers une institutionnalisation de la fonction contrôle interne ?. Comptabilité - Contrôle - Audit, Tome 12, 27-43. 
Chen, S., \& Komal, B. (2018). Audit committee financial expertise and earnings quality: A meta-analysis. Journal of Business Research, 84, 253-270.

Choi, J.-H., Jeon, K.-A., and Park J.-I. (2004). The role of audit committees in decreasing earnings management: Korean evidence. International Journal of Accounting, Auditing and Performance Evaluation, Vol.1 No.1, 37-60.

Collier, P., \& Gregory, A. (1999). Audit committee activity and agency costs. Journal of Accounting and Public Policy, 18 (1999) 311-332.

Darmayanti, Y., \& Md Kassim, A. A. (2019). The Effect of Female Directors and Financial Expertise of Audit Committees on Earnings Quality. Selangor Business Review, 4(2), 52-58.

DeZoort, F.T. (1998). An analysis of experience effects on audit committee members'oversight judgments. Accounting, Organizations and Society, Vol. 23, Issue 1, 1-21.

Francoeur, C., Labelle, R., \& Sinclair-Desgagné, B. (2008). Gender Diversity in Corporate Governance and Top Management. Journal of Business Ethics, Vol 81, 83-95.

Ghafran, C., \& O'Sullivan, N. (2013). The governance role of audit committees: Reviewing a decade of evidence. International Journal of Management Reviews, 15, 381-407.

Ghafran, C., \& Yasmin, S. (2018). Audit committee chair and financial reporting timeliness: A focus on financial, experiential and monitoring expertise. International Journal of Auditing, 22, 13 -24.

Goh, B. W. (2009). Audit Committees, Boards of Directors and Remediation of Material Weaknesses in Internal Control. Contemporary Accounting Research, 26, (2), 549-579.

Gull, A. A., Nekhili, M., Nagati, H., \& Chtioui, T. (2017). Beyond gender diversity: How specific attributes of female directors affect earnings management. The British Accounting Review, 50 (3), 255-274. 
Gurusamy, P. (2017). Board characteristics, audit committee and ownership structure influence on firm performance of manufacturing firms in India. International Journal of Business and Economics Research, 6 (4), 73-87.

Inaam, Z., and Khamoussi, H. (2016). Audit committee effectiveness, audit quality and earnings management: a meta-analysis. International Journal of Law and Management, Vol. 58 No. 2, 179-196.

Ittonen, K., Miettinen, J., Vähämaa S. (2010). Does female representation on audit committees affect audit fees?. Quarterly Journal of Finance and Accounting, Vol. 49, No. 3/4, 113-139.

Khemakhem, H., and Fontaine, R. (2019). The audit committee chair's abilities: Beyond financial expertise. International Journal of Auditing, Vol. 23, Issue 3, 457-471.

Khlif, H., and Samaha, K. (2016). Audit committee activity and internal control quality in Egypt: Does external auditor's size matter?. Managerial Auditing Journal, Vol. 31 No. 3, 269-289.

Klein, A. (2002). Audit Committee, board of director characteristics, and earnings management. Journal of Accounting and Economics, 33 (3): $375-400$.

Krishnan, G., and Visvanathan, G. (2009). Does the SOX Definition of an Accounting Expert Matter? The Association between Audit Committee Directors' Accounting Expertise and Accounting Conservatism. Contemporary Accounting Research, 25, 3, 827-858.

Krishnan, J. (2005). Audit Committee Quality and Internal Control: An Empirical Analysis. The Accounting Review, Vol. 80, No. 2, 649-675.

Lara, J. M. G., Osma, B. G., \& Mora, A. (2017). The monitoring role of female directors over accounting quality. Journal of Corporate Finance, 45 (C), 651-668.

Lisic, L. L., Myers, L. A., Seidel, T. A., \& Zhou, J. (2019). Does Audit Committee Accounting Expertise Help to Promote Audit Quality? 
Evidence from Auditor Reporting of Internal Control Weaknesses. Contemporary Accounting Research. Vol. 36, Issue 4, 2521-2553.

Lisic, L. L., Neal, T. L., Zhang, I. X., and Zhang, Y. (2016). CEO Power, Internal Control Quality, and Audit Committee Effectiveness in Substance Versus in Form. Contemporary Accounting Research, Vol. 33, Issue3, 1199-1237.

McMullen, D. A., and Raghundan, K. (1996). Enhancing audit committee effectiveness. Journal of Accountancy, (Août), 79-81.

Miglani, S. and Ahmed, K. (2019). Gender diversity on audit committees and its impact on audit fees: evidence from India Accounting Research Journal, Vol. 32 No. 4,568-586.

Naiker, V., \& Sharma, D. (2009). Former audit partners on the audit committee and internal control deficiencies. The Accounting Review, 84 (2), 559-587.

Nekhili, M., Gull, A. A., Chtioui, T., and Radhouane, I. (2020). Genderdiverse boards and audit fees: What difference does gender quota legislation make?. Journal of Business Finance and Accounting, Vol. 47, Issue1-2, 52-99.

Oussii, A., and Boulila Taktak, N. (2018). Audit committee effectiveness and financial reporting timeliness: The case of Tunisian listed companies. African Journal of Economic and Management Studies, Vol. 9 No. 1, 34-55.

Porettia, C., Schatt, A., and Bruynseels, L. (2018). Audit committees' independence and the information content of earnings announcements in Western Europe. Journal of Accounting Literature, 40, 29-53.

Pucheta-Martínez, M. C., Bel-Oms, I., \& Olcina-Sempere, G. (2016). Corporate governance, female directors and quality of financial information. Business Ethics: A European Reopinion, 25 (4), 363-385.

Qin, B. (2007). The influence of audit committee financial expertise on earnings quality: US evidence. ICFAI Journal of Audit Practice, 4 (3),7-28. 
Retnoningrum H., Agus Wahyudin, S., and Mahmud, A (2018). The Determinants of Audit Committee Meeting Frequency in Indonesia. The Social Sciences, Vol.13, Issue 3, 53-56.

Rich, K. T., and Zhang J. X. (2014). Does Audit Committee Monitoring Matter in the Government Sector? Evidence from Municipal Internal Control Quality. Journal of Governmental \&Nonprofit Accounting, 3 (1): 58-80.

Rohana, O., Ili Farhana I., Siti Maznah M. A., Nooraslinda A. A. (2014). Influence of Audit Committee Characteristics on Voluntary Ethics Disclosure. Procedia - Social and Behavioral Sciences, Vol. 145, 25, 330-342.

Sarens, G., De Beelde, I., and Everaert, P. (2009). Internal audit: A comfort provider to the audit committee. The British Accounting Review, Vol. 41, Issue 2, 90-106.

Sultana, N. (2015). Audit committee characteristics and accounting conservatism. International Journal of Auditing, 19 (2), 88-102.

Sultana, N., Singh, H., and Mitchell Van der Zahn, J-L. W. (2015). Audit Committee Characteristics and Audit Report Lag. International Journal of Auditing, Vol. 19, Issue2, 72-87.

Sun, J., Liu, G. and Lan G. (2011). Does female directorship on independent audit committees constrain earnings management?. Journal of Business Ethics, 99, 369-382.

Vlaminck, N., \& Sarens, G. (2015). The relationship between audit committee characteristics and financial statement quality: evidence from Belgium. Journal of Management \& Governance, 19 (1), 145-166.

Zhang, Y., Zhou, J., \& Zhou, N. (2007). Audit committee quality, auditor independence, and internal control weaknesses. Journal of accounting and public policy, 26(3), 300-327. 
